\title{
PEMILIHAN KEPALA DESA ANTAR WAKTU DI DESA ANJANI KECAMATAN SURALAGA KABUPATEN LOMBOK TIMUR
}

INTERTIME THE ELECTION HEAD OF VILLAGE IN ANJANI VILLAGE, DISTRICT OF SURALAGA, EAST LOMBOK REGENCY

\author{
Muhammad Adnan \\ Fakultas Hukum Universitas Gunung Rinjani \\ karangbaruadnan@gmail.com
}

\section{Info Artikel}

Sejarah Artikel :

Diterima 09 Nov 2021

Disetujui 19 Nov 2021

Publikasi November 2021

\section{Keyword:}

Election Of Village Head, Selection Between Time, Anjani Village

\section{Albstract}

The purpose of this study was to understand how the procedure of election head of village in Anjani Village District of Suralaga East Lombok Regency. And it also aims to understand what are the supporting factors and obstacles to the election head of village in Anjani Village District of Suralaga East Lombok Regency. This research examines the implementation of legal norms, in this case, legal norms about the intertime election (PAW) Village Head Election (Pilkades) with the selection of research locations conducted was purposively. This research is juridical-empirical, the data sources are library materials and the results of field interviews. The results of the research on the implementation of the inter-temporal Village Head Election in Anjani Village, Suralaga District, East Lombok Regency in 2021 carried out through an election mechanism with the village deliberation method led by the election committee based on the Minister of Home Affairs Regulation Number 65 of 2017 concerning Amendments to the Regulation of the Minister of Home Affairs Number 112 of 2014 about the Pilkades.

\section{Ahstrak}

Tujuan dari penelitian ini adalah untuk memahami bagaimana prosedur pemilihan Kepala Desa antar waktu di Desa Anjani Kecamatan Suralaga Kabupaten Lombok Timur. Dan juga bertujuan untuk memahami apa saja faktor pendukung dan penghambat pemilihan Kepala Desa antar waktu di Desa Anjani Kecamatan Suralaga Kabupaten Lombok Timur. Penelitian ini meneliti tentang pelaksanaan norma hukum, dalam hal ini norma hukum tentang pergantian antar waktu (PAW) Pemilihan Kepala Desa (Pilkades) dengan pemilihan lokasi penelitian dilakukan secara purposive. Jenis penelitian ini adalah yuridis-empirik yang sumber datanya dari bahan Pustaka dan hasil wawancara dilapangan. Hasil penelitian pelaksanaan Pemilihan Kepala Desa antar waktu di Desa Anjani Kecamatan Suralaga Kabupaten Lombok Timur Tahun 2021 dilaksanakan melalui mekanisme pemilihan dengan metode musyawarah desa yang dipimpin oleh panitia pemilihan berdasarkan Peraturan Menteri Dalam Negeri Nomor 65 Tahun 2017 tentang Perubahan Peraturan Menteri Dalam Negeri Nomor 112 tahun 2014 tentang Pilkades. 


\section{A. PEndahuluan}

Negara Kesatuan Republik Indonesia adalah sebuah negara yang menjalankan pemerintahan dengan menganut sistem demokrasi. Demokrasi sendiri berarti bahwa semua warga negara memiliki hak yang sama dalam hal pengambilan keputusan. Sehingga sistem demokrasi dilaksanakan berdasarkan kehendak rakyat yang dilaksanakan oleh rakyat untuk kepentingan rakyat itu sendiri, karena kedaulatan tertinggi dari sebuah Negara berada di tangan rakyat yang dilaksanakan menurut Peraturan UndangUndang Dasar. ${ }^{1}$

Karakteristik Negara dengan sistem pemerintahan demokrasi adalah pelibatan rakyat negara itu sendiri dalam hal yang berkaitan dengan pengambilan keputusan yang bersifat politik baik secara langsung ataupun tidak langsung dengan sistem perwakilan. Sistem perwakilan tersebut dilakukan dengan pemilihan umum (pemilu) setiap lima tahun di Indonesia baik dalam memilih Kepala Negara dan Wakil Kepala Negara maupun dalam memilih wakil rakyat. Demikian pula pemilihan Kepala Daerah sampai tingkat terkecil yakni pemilihan Kepala Desa.

Partisipasi rakyat dalam pemilu atau pemilihan umum merupakan bentuk karakteristik dari sistem pemerintahan yang menganut sistem demokratis, termasuk didalamnya pemilihan Kepala Desa (pilkades) yang dilakukan secara langsung, umum, bebas, rahasia, jujur dan adil, sebagaimana prinsip-prinsip dalam pelaksanaan pemilihan umum. Proses Pilkades bertujuan untuk memilih pemimpin ditingkat paling bawah yang mana didalamnya melibatkan masyarakat setempat, baik yang jadi calon Kepala Desa, panitia bahkan pengawas dan proses dan hasilnya dirasakan langsung oleh masyarakat Desa itu sendiri.

Peraturan perundang-undangan yang khusus mengenai pilkades terdapat dalam UU 6/2014 tentang Desa yang sebelumnya merupakan revisi atau perubahan dari UU 32/2004 tentang Pemerintahan Daerah yang mengakui pemerintah Desa sebagai salah satu bagian dari pemyelenggaraan

${ }^{1}$ Pemerintah Indonesia, Pasal 1 ayat (2) UndangUndang Dasar Negara Republik Indonesia Tahun 1945 Tentang Kedaulatan Rakyat. pemerintahan yang memiliki hak dan wewenang dalam hal mengurus pemerintahan pada tingkat Desa. ${ }^{2}$

Secara konseptual Pilkades ini memiliki hubungan erat dengan upaya pemerintah dalam mewujudkan tujuan dari otonomi pemerintahan Desa itu sendiri, dengan cara mewujudkan pemerintahan yang demokratis serta meningkatkan taraf kesejahteraan masyarakat Desa. Adanya otonomi Desa ini memberikan pengakuan pada Desa atas hak mereka dalam mengurus dan menjalankan pemerintahannya sendiri degan landasan prakarsa masyarakat namun tetap tidak bertentangan dengan peraturan perundangundangan yang berlaku. ${ }^{3}$

Pemilihan Kepala Desa (Pilkades) merupakan sebuah instrumen dalam pembentukan pemerintahan modern dan demokratis. Dimana Pilkades menjadi bentuk praktek penyaluran kehendak rakyat di wilayah Desa. Kepala Desa dipilih secara langsung oleh rakyat melalui Pilkades. Sehingga proses pemilihan Kepala Desa dikatakan sebagai bentuk asli demokrasi dan sekaligus ciri manifestasi dari kehidupan demokrasi pancasila. ${ }^{4}$

Seperti yang diketahui penentuan pemimpin Desa adalah hal krusial dalam menjalankan kedaulatan, disebabkan posisi Kepala Desa yang memiiliki peran penting dalam menjalankan fungsi pemerintahan pada tingkat Desa. Didefinisikan bahwa Desa merupakan persatuan individu dalam hukum yang mempunyai perbatasan wilayah untuk melaksanakan wewenang dalam mengatur pemerintahannya, sehingga masyarakat Desa memiliki hak asal-usul atau tradisional yang diakui dalam pemerintahan Republik Indonesia karena setiap Desa memiliki adat dan budaya yang berbeda. ${ }^{5}$

Berkaitan dengan pengakuan dan penghormatan norma masyarakat disertai wewenangnya, ditegaskan oleh Undang-

\footnotetext{
2 Republik Indonesia, Undang-Undang Nomor 6 tahun 2014 tentang Desa, pasal 1 ayat (1)

3 Juliantara, Dadang, Pembahuruan Desa, Bertumpu Pada Angka Terbawah. (Yogyakarta: Lappera Pustaka Utama, 2003), hlm.116.

4 Daeng Sudirwo. Pokok-Pokok Pemerintahan di Daerah dan Pemerintah Desa, Angkasa. Bandung, 1981, hlm 52.

${ }^{5}$ Republik Indonesia, Undang-Undang Nomor 6 tahun 2014 Tentang Desa, pasal 1 ayat (1)
} 
Undang Dasar 1945. ${ }^{6}$ Otoritas tingkat Desa adalah unsur pemerintahan yang terbawah pada sistem otoritas di Negara Indonesia, otoritas Desa memiliki keterlibatan dan interaksi langsung terhadap penduduk Desa, golongan, keperluan maupun konflik sistem kemasyarakatan. Sehingga

ini mengindikasikan bahwasanya apabila otoritas pada tingkat Desa dilaksanakan secara benar tanpa ada penyelewengan berdasarkan peraturan yang telah ditentukan, maka ini tentu akan memberikan pengaruh signifikan terhadap peningkatan berbagai aspek di lingkungan masyarakat itu sendiri.

Sebagaimana yang telah diuraikan diatas, dengan diundangkannya peraturan yang berkenaan dengan Desa secara khusus yakni Undang-Undang Nomor 6 Tahun 2014 tentang Desa selanjutnya disingkat dan telah menjadi pengetahuan umum dengan sebutan UU Desa memberikan pengaruh terhadap sistem penetapan pemimpin Desa.

Merujuk pada UU Desa disebutkan bahwa pemilihan Kepala Desa dilaksanakan secara serentak di wilayah Kabupaten/Kota, yang kebijakan pelakasanaannya ditetapkan oleh Otoritas Daerah Kabupaten/Kota. Sehubungan dengan tata cara atau proses pemilihan Kepala Desa serentak diatur dengan atau berdasarkan Peraturan Pemerintah.7

Dalam UU Desa mengatur pelaksanaan pilkades, yang mana setiap wilayah harus mempunyai Peraturan Daerah yang khusus mengatur perihal pilkades. Selain itu penentuan pemimpin desa ditentukan pula dalam Peraturan Pemerintah yang menjadi bentuk dari dilaksanakannya Undang-Undang serta Peraturan Menteri Dalam Negeri yang memiliki fungsi sebagai tolak ukur setiap Desa dalam hal perumusan perda prihal pemilihan Kepala Desa. Untuk saat ini Peraturan Pemerintah (PP) perihal penyelengaraan dari UU desa terdapat pada PP No. 47 Tahun 2015 tentang Perubahan PP No. 43 Tahun 2014 tentang Peraturan Pelaksanaan UU No. 6 Tahun 2014 Tentang Desa serta Permendagri Nomor 65 tahun 2017 atas perubahan Permendagri Nomor

\footnotetext{
${ }^{6}$ Republik Indonesia, Undang-Undang Dasar Negara Republik Indonesia Tahun 1945, Pasal 18B ayat (2)

7 Republik Indonesia, Undang-Undang Nomor 6 tahun 2014 Tentang Desa, pasal 31 ayat (1)
}

112 tahun 2014 tentang pemilihan Kepala Desa yang terakhir dirubah dengan Permendagri No. 72 Tahun 2020 tentang Perubahan Kedua Permendagri No. 112 Tahun 2014 tentang Pilkades.

Diselenggarakannya pemilihan Kepala Desa berpatokan pada aturan yang ditetapkan pemerintah yang kemudian disahkan oleh DPR pusat maupun daerah berdasarkan peraturan hukum ditingkat nasional ataupun regional. Perlu diketahui bahwa bukan merupakan rahasia umum bahwa pelaksanaan demokrasi pertama berada di tingkatan desa, disebabkan sekitar dua abad yang lalu saat masih Hindia Belanda, masyarakat desa telah melaksanakan pemilihan umum untuk memilih pemimpin mereka. Hal tersebut memberikan petunjuk bahwa pemilihan secara demokratis telah dimulai sejak zaman Hindia Belanda dan masih dilakukan hingga sekarang, disebabkan masyarakat desa telah terbiasa memilih pemimpin mereka dengan diberikan hak suara kepada tiap calon. ${ }^{8}$

Sebagai bagian dari Negara Indonesia, Kabupaten Lombok Timur telah mengesahkan Peraturan Daerah atau Perda Kabupaten Lombok Timur Nomor 4 tahun 2015, tentang Tata Cara Pemilihan serta Pemberhentian Kepala Desa. Disahkannya Perda ini pada saat H. Moch. Ali Bin Dachlan menjabat sebagai Bupati Lombok Timur dan mengesahkan Peraturan Bupati Lombok Timur Nomor 15 Tahun 2016 tentang Tata cara pelaksanaan Perda No. 4 Tahun 2015. ${ }^{9}$

Selain mengatur pilkades secara serentak juga mengatur pilkades antar waktu terkait dengan Kepala Desa yang berhenti atau diberhentikan, namun perda dan perbup itu belum mengatur secara lebih teknis mengenai Pilkades antar waktu, hal ini diharapkan menjadi landasan hukum bagi Desa agar tidak terjadinya kekosangan jabatan dalam pemerintahan Desa.

Dalam pelaksanaan pemerintahan suatu Desa tidak terlepas dari peran pemerintah Desa dalam hal ini Kepala Desa dan

8 Hulaimi. 2021. "Analisis Yuridis Penyelesaian Sengketa Kepala Desa yang Mendapat Suara Sama Di Desa Masbagik Selatan Kabupaten Lombok Timur", JURIDICA: Jurnal Fakultas Hukum Universitas Gunung Rinjani 2(2): 4-20 https://doi.org/10,46601/juridica. $\underline{\mathrm{v} 2 \mathrm{i} 2.189}$.

${ }^{9}$ Ibid 
jajarannya dan BPD sebagai unsur pemerintahan desa. Pemilihan Kepala Desa dilaksanakan dengan pemilihan langsung oleh masyarakat di desa tersebut yang mekanismenya telah ditentukan dalam peraturan perundang-undangan. Masa jabatan Kepala Desa yaitu enam tahun dan dapat menjabat paling lama 3 (tiga) kali masa jabatan secara berturut-turut atau tidak secara berturut-turut. ${ }^{10}$

Pemerintahan tingkat desa adalah benteng utama dalam diselenggarakannya otoritas kenegaraan, hal ini disebabkan oleh intraksi yang terjadi secara langsung antara masyarakat dengan Kepala Desa yang merupakan bagian dari kekuasaan pemerintah lebih sering terjadi pada sistem pemerintahan pada tingkat Desa. Kepala Desa sebagai penyelenggara dan pengurus pemerintahan Desa mempunyai kewajiban untuk membela, melindungi, memberikan pengetahuan dan sosialisasi serta meningkatkan taraf kesejahteraan dan kehidupan masyarakat Desa itu sendiri.

Kepala Desa yang merupakan pemimpin tertinggi ditingkat Desa yang menyelenggarakan dan berperan sebagai penanggung jawab utama dalam hal pemerintahan, pembangunan serta yang berkaitan dengan pemberdayaan masyarakat. Selain itu seorang Kepala Desa juga memiliki tanggung jawab dalam hal menciptakan serta meningkatkan rasa persatuan serta menciptakan rasa aman. Oleh karenanya sangat dibutuhkan pemimpin Desa yang mempunyai pengabdian tinggi untuk masyarakat serta wilayah yang dipimpinnya dalam menjalankan amanah yang diberikan oleh masyarakat Desa sesuai dengan peraturan perUndang-Undangan yang berlaku.

Dalam peraturan perundang-undangan telah diatur yaitu penenetuan pemimpin Desa tidak dapat diselenggarakan secara sementara melainkan diselenggarakan serentak diseluruh wilayah Kabupaten/Kota. Sebelum diundangkannya Undang Undang Desa, dijelaskan bahwa jika Kepala Desa telah diberhentikan sebelum masa jabatannya habis, akan menunggu sampai waktu yang telah di tentukan untuk dapat

10 Republik Indonesia, Peraturan Pemerintahan Nomor 43 tahun 2014 Pasal 47 melakukan pemilihan Kepala Desa kembali. Namun setelah diundangkannya UndangUndang Desa, pemilihan Kepala Desa dilaksanakan secara serentak, tentunya hal ini akan berdampak bagi Desa yang Kepala Desanya diberhentikan sebelum habis masa jabatannya, tentu akan terjadi kekosongan jabatan Kepala Desa sampai dengan adanya ketentuan dilaksanakannya pilkades serentak tersebut. Untuk mengantisipasi kekosongan jabatan samapi dengan adanya jadwal pilkades serentak, maka diaturlah mekanisme pergantian waktu Kepala Desa, seiring dengan adanya UU Desa.

Dipilihnya Kepala Desa yang merupakan penggantian antar waktu telah diatur dalam Undang-Undang Desa yang menegaskan, jika sisa masa jabatan Kepala Desa yang berhenti atau diberhentikan lebih dari satu tahun, maka Bupati atau Wali Kota akan mengangkat seorang Pegawai Negeri Sipil dari Pemerintah Daerah Kabupaten/Kota yang akan mengisi posisi jabatan Kepala Desa sementara. Penjabat Kepala Desa yang diangkat tetap menjalankan kewajiban dan wewenang, maupun hak yang dimiliki oleh Kepala Desa sebagaimana mestinya hingga dilaksanakannya Musyawarah Khusus Desa untuk melaksanakan Pemilihan Kepala Desa antar waktu.

Dalam hal pemilihan Kepala Desa antar waktu melaui musyawarah Desa akan diselenggarakan paling lambat 6 bulan setelah diberhentikannya Kepala Desa, kemudian Kepala Desa yang telah terpilih dalam Musyawarah Desa yang akan melaksanakan tugas dan kewajiban Kepala Desa yang diberhentikan sampai habis sisa masa jabatannya. Hal ini berbeda dengan peraturan sebelumnya sebagaimana yang terdapat dalam PP Nomor 72 Tahun 2005 Pasal 22 menyatakan bahwa jika Kepala Desa yang menjabat diberhentikan, Bupati atau Walikota selaku pihak yang berwewenang melantik Kepala Desa disertai tugas dan wewenang yang sama dengan sebelumnya, dan pemilihannya dilakukan paling lambat 6 bulan sejak pengadilan memutuskan perkara.

Pembaruan dalam prosesi pemilihan Kepala Desa muncul setelah terbitnya regulasi tentang Pilkades antar waktu. Istilah ini baru dikenal sejak diundangkannya UU Nomor 6 Tahun 2014 tentang Desa. Dalam perihal Kepala Desa yang diberhentikan 
dengan sisa masa jabatan lebih dari 1 (satu) tahun, maka diselenggarakan Pilkades antar waktu melalui musyawarah Desa. ${ }^{11}$

Pedoman teknis penyelenggaraan Pilkades antar waktu telah dijabarkan secara rinci dalam pasal 45 PP Nomor 43 Tahun 2014 tentang peraturan pelaksanaan UU Nomor 6 Tahun 2014 tentang Desa. Ketentuan lanjutan tentang mekanisme pelaksanaan Pilkades antar waktu tertuang dalam Permendagri Nomor 65 tahun 2017 dalam pasal 47A-47E yang merupakan amanah dari pasal 46 PP Nomor 45 tahun 2017 atas perubahan peraturan Pemerintah nomor 43 tahun 2014 tentang peraturan pelaksanaan Undang-Undang Nomor 6 Tahun 2014 tentang Desa yang mengatakan bahwa ketentuan lebih lanjut mengenai pemilihan Kepala Desa diatur dengan Peraturan Menteri yang menyelenggarakan urusan pemerintahan dibidang Pemerintahan Dalam Negeri. Namun, perubahan peraturan perUndang-Undangan tidak diriringi dengan perubahan ditingkat Perda atau Perbup khususnya di Lombok Timur yang terkait dengan pergantian waktu Kepala Desa.

Beberapa Desa di Kabupaten Lombok Timur telah melaksanakan pemilihan Kepala Desa antar waktu diantaranya Desa Anjani, Desa Rempung, Desa Rensing, Desa Bagik Payung Timur dan Desa Banjar Sari. Hal ini menunjukan bahwa Kabupaten Lombok Timur dapat menjadi tolak ukur untuk melihat bagaimana aturan tersebut dapat dijalankan secara das solen maupun das sein pemilihan Kepala Desa Antar Waktu berdasarkan peraturan yang yang telah ditetapkan. Adapun berdasarkan hal-hal yang diuraikan dalam latar belakang diatas, maka penulis mengidentifikasikan masalah-masalah yang perlu diuraikan dalam melalui tulisan ini, yaitu: 1). bagaimana prosedur pemilihan Kepala Desa Antar Waktu; dan 2). apa saja faktor pendukung dan penghambat pemilihan Kepala Desa antar waktu di Desa Anjani Kecamatan Suralaga Kabupaten Lombok Timur.

\section{B. METODE PENELITIAN}

Penelitian ini meneliti tentang pelaksanaan norma hukum, dalam hal ini

11 Republik Indonesia, Undang-Undang Nomor 6 tahun 2014 tentang Desa, Pasal 47 norma hukum tentang pergantian antar waktu (PAW) Pemilihan Kepala Desa (Pilkades). Norma hukum ini dilaksanakan oleh Badan Permusyawaratan Desa (BPD) dalam Musyawarah Desa untuk pergantian kepala desa dengan mekanisme PAW. Sebagai penelitian deskriptif penelitian ini menggambarkan tentang pelaksanaan Pilkades dengan mekanisme PAW melalui musyawarah desa di Desa Anjani Kecamatan Suralaga Kabupaten Lombok Timur.

Pemilihan lokasi penelitian dilakukan secara purposive, jadi berdasarkan tujuantujuan tertentu, yang terutama adalah karena tujuan untuk memudahkan pencarian dan pengumpulan data. Pemilihan lokasi pada Desa Anjani, juga disertai asumsi bahwa apa yang terjadi di lokasi penelitian juga menggambarkan apa yang terjadi di tempat lain, sehingga dapat ditarik suatu generalisasi.

Ada dua sumber data digunakan dalam penelitian ini, yaitu sumber data kepustakaan dan sumber data lapangan. Dari sumber data kepustakaan dikumpulkan data sekunder berupa bahan-bahan hukum. Dari sumber data lapangan dikumpulkan data primer yang relevan. Bahan-bahan hukum yang dipakai dalam penelitian ini di antaranya:

(1) Bahan Hukum primer berupa UndangUndang, Peraturan Pemerintah, Permendagri yang utama adalah Peraturan Daerah atau Perda Kabupaten Lombok Timur Nomor 4 tahun 2015, tentang Tata Cara Pemilihan serta Pemberhentian Kepala Desa dan Peraturan Bupati Lombok Timur Nomor 15 Tahun 2016 tentang Tata cara pelaksanaan Perda No. 4 Tahun 2015.

(2) Bahan hukum sekunder berupa pendapat ahli yang ditulis dalam bentuk buku, maupun hasil-hasil penelitian.

Penelitian ini mempergunakan beberapa teknik pengumpulan data seperti: a. Teknik studi dokumentasi/ kepustakaan; dan b. Teknik wawancara berencana/terstruktur. Analisis Data adalah mengorganisasikan dan menguraikan data ke dalam pola, kategori dan satuan uraian dasar sehingga dapat 
ditemukan sesuai masalah penelitian ${ }^{12}$. Analisis dilakukan secara kualitatif dengan alur pengolahan data sebagai berikut: data dikumpulkan kemudian disusun secara sistematis, direduksi, dipaparkan secara sistematis, dan ditarik simpulan sebagai jawaban atas permasalahan. ${ }^{13}$

\section{PEMBAHASAN}

\section{Kekosongan Jabatan Kepala Desa di Desa Anjani}

Desa Anjani merupakan salah satu desa yang terletak di wilayah Kecamatan Suralaga Kabupaten Lombok Timur. Dengan jumlah penduduk yaitu 11.019 jiwa terdiri dari lakilaki berjumlah 5.462 jiwa dan perempuan 5.557 jiwa pada tahun 2021. Desa Anjani terdiri dari 8 (Delapan) Dusun yaitu: Dusun Anjani Barat, Dusun Anjani Timur, Dusun Anjani Selatan I, Dusun Anjani Selatan II, Dusun Kerembong, Dusun Darul Hijrah, Dusun Banjar Manis dan Dusun Penakak. Secara geografis Desa Anjani berbatasan dengan Desa Suralaga di sebelah Utara, Desa Rempung di sebelah Selatan, Desa Gapuk di sebelah Barat berbatasan dengan Desa Gapuk dan Desa Bintang Rinjani di sebelah Timur.

Desa Anjani merupakan salah satu dari 6 (enam) desa pertama yang meyelenggarakan Pilkades Antar Waktu di Kabupaten Lombok Timur, setelah hadirnya UU 6/2014 tentang Desa. Kepala Desa Anjani sebelumnya, almarhum H.M. Zulkarnaen meninggal dunia pada hari minggu tanggal 4 Oktober 2020, dengan sisa masa jabatan 3 (tiga) tahun, 4 (empat) bulan, 2 (dua) hari. ${ }^{14}$

Pesta demokrasi ditingkat administrasi terkecil ini, pada dasarnya di lakukan guna menindaklajuti pemberhentian kepala desa berdasarkan peraturan perundang-undangan yang berlaku. Hal tersebut sebaimana di atur dalam Pasal 40 ayat (1) UU 6/ 2014 tentang Desa, yang menyebutkan bahwa : "Kepala Desa berhenti karena :
a) meninggal dunia;
b) permintaan sendiri; atau diberhentikan."

\footnotetext{
12 Moleong, L.J. Metodologi Penelitian. Bandung: PT Remaja Rosda Karya, 1999, hlm. 103

13 Soekanto, Soerjono, Pengantar Penelitian Hukum, UI Press; Jakarta, 1986, hlm. 250

14 Nurmin, wawancara, panitia pilkades antar waktu (23 Agustus 2021)
}

Merujuk pada muatan pasal tersebut, penyelenggaraan Pilkades harus segera dilaksanakan untuk mengisi kekosongan jabatan kepala desa. Dalam aturan terbaru apabila kepala desa diberhentikan dalam sisa masa jabatan lebih dari 1 (satu) tahun, maka di adakan pemilihan kepala desa antar waktu melalui musyawarah desa. Hal tersebut merupakan amanat dari Pasal 47 UU 6/2014 tentang Desa yang menyebutkan bahwa :

(1) Dalam hal sisa masa jabatan kepala desa yang diberhentikan sebagaimana dimaksud dalam Pasal 43 lebih dari 1 (satu) Tahun, Bupati/Walikota mengangkat pegawai negeri sipil dari Pemerintah Daerah Kabupaten/Kota sebagai penjabat Kepala Desa.

(2) Penjabat Kepala Desa sebagaimana dimaksud pada ayat (1) melaksanakan tugas, wewenang, kewajiban, dan hak Kepala Desa sebagaimana dimaksud dalam Pasal 26 sampai dengan ditetapkannya Kepala Desa.

(3) Kepala Desa sebagaimana dimaksud pada ayat (2) dipilih melalui Musyawarah Desa yang memenuhi persyaratan sebagaimana dimaksud dalam Pasal 33.

(4) Musyawarah Desa sebagaimana dimaksud pada ayat (3) dilaksanakan paling lama 6 (enam) bulan sejak Kepala Desa diberhentikan.

(5) Kepala Desa yang dipilih melalui Musyawarah Desa sebagaimana di maksud pada ayat (3) melaksanakan tugas Kepala Desa sampai habis sisa masa jabatan Kepala Desa yang diberhentikan.

(6) Ketentuan lebih lanjut mengenai Musyawarah Desa sebagaimana dimaksud pada ayat (3) diatur dalam Peraturan Pemerintah.

Pengaturan lebih lanjut pemilihan kepala desa antar waktu melalui musyawarah desa diatur dalam Pasal 45 Peraturan Pemerintah Nomor 43 Tahun 2014 yang menyebutkan bahwa :

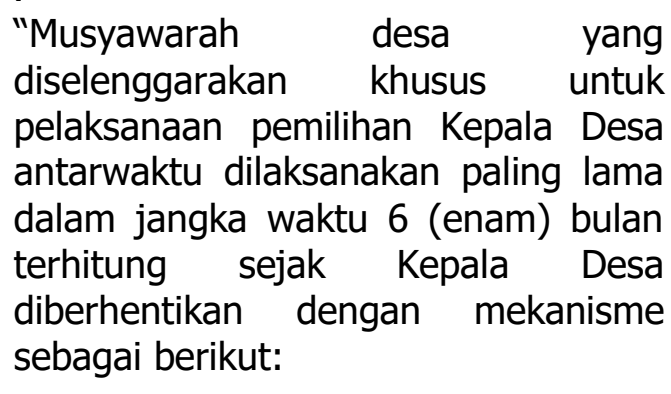


a. Sebelum penyelenggaraan musyawarah Desa, dilakukan kegiatan yang meliputi:

(1) pembentukan panitia pemilihan Kepala Desa antarwaktu oleh Badan Permusyawaratan Desa paling lama dalam jangka waktu 15 (lima belas) Hari terhitung sejak Kepala Desa diberhentikan;

(2) pengajuan biaya pemilihan dengan beban APBDesa oleh panitia pemilihan kepada penjabat Kepala Desa paling lambat dalam jangka waktu 30 (tiga puluh) Hari terhitung sejak panitia terbentuk;

(3) pemberian persetujuan biaya pemilihan oleh penjabat Kepala Desa paling lama dalam jangka waktu 30 (tiga puluh)Hari terhitung sejak diajukan oleh panitia;

(4) pengumuman dan pendaftaran bakal calon Kepala Desa oleh panitia pemilihan dalam jangka waktu 15 (lima belas) Hari;

(5) penelitian kelengkapan persyaratan administrasi bakal calon oleh panitia pemilihan dalam jangka waktu 7 (tujuh) Hari; dan

(6) penetapan calon Kepala Desa antarwaktu oleh panitia paling sedikit 2 (dua) orang calon dan paling banyak 3(tiga) orang calon yang dimintakan pengesahan musyawarah Desa untuk di tetapkan sebagai calon yang berhak dipilih dalam musyawarah Desa.

b. Badan Permusyawaratan Desa (BPD) menyelenggarakan musyawarah Desa yang meliputi kegiatan:

(1) penyelenggaraan musyawarah Desa dipimpin oleh Ketua Badan Permusyawaratan Desa yang teknis pelaksanaan pemilihannya dilakukan oleh panitia pemilihan;

(2) pengesahan calon Kepala Desa yang berhak dipilih oleh musyawarah Desa melalui musyawarah mufakat atau melalui pemungutan suara;

(3) pelaksanaan pemilihan calon Kepala Desa oleh panitia pemilihan melalui mekanisme musyawarah mufakat atau melalui pemungutan suara yang telah disepakati oleh musyawarah Desa;
(4) pelaporan hasil pemilihan calon Kepala Desa oleh panitia pemilihan kepada musyawarah Desa;

(5) pengesahan calon terpilih oleh musyawarah Desa;

(6) pelaporan hasil pemilihan Kepala Desa melalui musyawarah Desa kepada BPD dalam jangka waktu 7(tujuh) Hari setelah musyawarah Desa mengesahkan calon Kepala Desa terpilih;

(7) pelaporan calon Kepala Desa terpilih hasil musyawarah Desa oleh ketua Badan Permusyawaratan Desa kepada bupati/walikota paling lambat 7 (tujuh) Hari setelah menerima laporan dari panitia pemilihan;

(8) penerbitan keputusan Bupati/ walikota tentang pengesahan pengangkatan calon Kepala Desa terpilih paling lambat 30 (tiga puluh) Hari sejak diterimanya laporan dari Badan Permusyawaratan Desa; dan

(9) pelantikan Kepala Desa oleh bupati/walikota paling lama 30 (tiga puluh) Hari sejak diterbitkan keputusan pengesahan pengangkatan calon Kepala Desa terpilih dengan urutan acara pelantikan sesuai dengan ketentuan peraturan perundang-undangan.

Merujuk pada pasal tersebut, musyawarah desa menjadi forum resmi yang ditunjuk oleh Undang-Undang untuk mengakomodir penyelanggaraan pemilihan kepala desa antar waktu. Sebagaimana diatur dalam Pasal 54 ayat (1) UU Desa:

"Musyawarah Desa merupakan forum permusyawaratan yang diikuti oleh Badan Permusyawaratan Desa, Pemerintah Desa, dan unsur masyarakat desa untuk memusyawarahkan hal yang bersifat strategis dalam penyelenggaraan Pemerintahan Desa".

Selanjutnya ditambahkan dalam Pasal 80 PP 45/2014: (1) Musyawarah Desa diselenggarakan oleh BPD yang difasilitasi oleh Pemerintah Desa. (2) Musyawarah Desa sebagaimana dimaksud pada ayat (1) diikuti oleh Pemerintah Desa, BPD, dan unsur masyarakat. (3) Unsur masyarakat sebagaimana dimaksud pada ayat (2) terdiri 
atas: a. tokoh adat; b. tokoh agama; c. tokoh masyarakat; d. tokoh pendidikan; e. perwakilan kelompok tani; f. perwakilan kelompok nelayan; g. perwakilan kelompok perajin; h. perwakilan kelompok perempuan; i. perwakilan kelompok pemerhati dan pelindungan anak; j. perwakilan kelompok masyarakat miskin.

Susunan kepanitian pemilihan kepala desa antar waktu dibentuk melalui musyawarah desa yang diselenggarakan oleh BPD. Biaya pelaksanaan Pilkades dibebankan kepada APBDesa. Pemilihan kepala desa antar waktu dilaksanakan melalui musyawarah mufakat atau pemungutan suara. Mekanisme tersebut sebagaimana telah diatur dalam Pasal 45b ayat (3) PP Nomor 43/2014 bahwa:

"Pelaksanaan pemilihan calon Kepala Desa oleh panitia pemilihan melalui mekanisme musyawarah mufakat atau melalui pemungutan suara yang telah disepakati oleh musyawarah Desa."

Tahapan penyelenggaraan Pilkades antar waktu tidak jauh berbeda dengan Pilkades langsung serentak. Namun model pelaksanaan Pilkades antar waktu didesain lebih sederhana. Berdasarkan amanat UU Desa, forum musyawarah desa ditunjuk untuk mengakomodir pelaksanaan Pilkades antar waktu. Kepala Desa terpilih di daulat untuk melanjutkan sisa masa jabatan kepala desa yang diberhentikan. Penyelenggaraan pemilihan kepala desa kembali dilaksanakan secara langsung serentak berdasarkan gelombang waktu setelah masa jabatan kepala desa antar waktu berakhir.

Karena adanya kekosongan jabatan Kepala Desa Anjani, hal ini di tindak lanjuti oleh BPD Anjani dengan pengusulan Pejabat Kepala Desa Anjani kepada Bupati Lombok Timur. Berdasarkan Surat Keputusan Bupati Lombok Timur, Nomor 188.45/571/PMD/2020 Tanggal 26 Oktober 2020 Tentang Pengangkatan Pejabat Kepala Desa Anjani dan Abdul Hakim selaku Kasi PMD Kecamatan Suralaga di tetapkan sebagai Penjabat Kepala Desa Anjani yang tugas utamanya adalah menyelenggarakan Pilkades Antar Waktu.

\section{Prosedur Pemilihan Kepala Desa antar waktu di Desa Anjani Kecamatan Suralaga}

(1) Pembentukan Panitia

Pembentukan panitia pemilihan Kepala Desa antar waktu Desa Anjani dilaksanakan oleh BPD Anjani yang dihadiri oleh semua anggota BPD, Pj Kepala Desa, Perangkat Desa dan Forkopimda Kecamatan Suralaga.

Panitia Pilkades antar waktu disusun berdasarkan hasil Musyawarah Desa dan ditetapkan dalam Surat Keputusan (SK) Badan Permusyawaratan Desa (BPD) Anjani Kecamatan Suralaga Kabupaten Lombok Timur Nomor 143/8/BPD/2021 tentang Pembentukan Panitia Pilkades Antar Waktu Desa Anjani.

Adapun susunan panitia pilkades antar waktu Desa Anjani Kecamatan Suralaga Kabupaten Lombok Timur adalah:

\begin{tabular}{|c|c|c|c|}
\hline No & Nama & Unsur & Jabatan \\
\hline 1 & Ahmad, SH & Masyarakat & Ketua \\
\hline 2 & Abdurrahman & Perangkat Desa & Sekretaris \\
\hline 3 & H.Mawardi, S.Pd & Masyarakat & Anggota \\
\hline 4 & Ibrahim, SP & Masyarakat & Anggota \\
\hline 5 & Zaini Ahyat, SE & Perangkat Desa & Anggota \\
\hline 6 & Zanuardi, & Masyarakat & Anggota \\
\hline 7 & $\begin{array}{l}\text { M.Syarif } \\
\text { Hidayatulloh }\end{array}$ & Perangkat Desa & Anggota \\
\hline $\begin{array}{l}\text { Sum } \\
04 / A\end{array}$ & $\begin{array}{l}\text { er : lampiran } \\
\text { 3PD/Anj/I/2021 }\end{array}$ & SK BPD Anjani & Nomor \\
\hline
\end{tabular}

Berdasarkan Peraturan Bupati Lombok Timur Nomor 21 Tahun 2017 Tentang Perubahan atas Peraturan Bupati Nomor 15 tahun 2016 tentang Peraturan Pelaksanaan Peraturan Daerah Nomor 4 tahun 2015 Tentang Tata Cara Pemilihan dan Pemberhentian Kepala Desa pasal 14A, Panitia Pemilihan mempunyai kewajiban:
a) melaksanakan semua tahapan penyelenggaraan pemilihan Kepala Desa;
b) memperlakukan peserta pemilihan calon kepala desa secara adil dan setara;
c) menyampaikan semua infromasi kepada masyarakat; penylenggaraan pemilihan kepala desa
d) mempertanggungjawabkan penggunaan anggaran pelaksanaan pemilihan kepala Desa; dan
e) membuat berita acara pada setiap rapat pleno sesuai ketentuan peraturan perundang-undangan;
f) menyampaikan laporan pertanggungjawaban semua kegiatan penyelenggaraan pemilihan kepala Desa 
kepada BPD dan Panitia Pemilihan Kabupaten disertai dokumen- dokumen pemilihan kepala desa. ${ }^{15}$

(2) Penyusunan Rencana Anggaran Pilkades Suksesnya Pemilihan Kepala Desa antar waktu tidak terlepas dari tersedianya anggaran yang memadai. Untuk Efisiensi dan tepat sasaran penggunaan dana tentunya Panitia Pilkades menyusun anggaran secara akurat dan akuntable, mengingat sumber dana Pilkades antar waktu ini adalah bersumber dari APBDes. Hal ini sesuai dengan Peraturan Bupati Lombok Timur Nomor 5 Tahun 2021 Tentang Perubahan Ke Tiga atas Peraturan Bupati Nomor 15 tahun 2016 Tentang perturan pelaksanaan Peraturan Daerah Nomor 4 tahun 2015 tentang tata cara pemilihan dan pemberhentian kepala Desa pasal 74 ayat (3) yang berbunyi: " Biaya pemilihan Kepala Desa anatr waktu melalui musyawarah Desa dibebankan pada anggaran pendapatan belanja Desa." 16

Adapun total anggaran yang dihabiskan dalam pilkades antar waktu yang bersumber dari APBDes Desa Anjani Kecamatan Suralaga Kabupaten Lombok Timur berjumlah sekitar Rp 37.000.000, (tiga puluh tujuh juta rupiah) hal ini menunjukkan biaya pemilihan pilkades anatar waktu lebih efisien dibandingkan dengan pilkades langsung yang pernah dilaksanakan sebelumnya, karena pada saat pilkades langsung panitia mengahabiskan anggaran sekitar Rp 85.000.000 (Delapan Puluh Lima Juta Rupiah). ${ }^{17}$

(3) Pengajuan dan Persetujuan anggaran Pilkades

Sesuai dengan amanat Peraturan Pemerintah Nomor 43 tahun 2014 di jelaskan bahwa pengajuan anggaran pilkades oleh panitia pilkades kepada Pejabat Desa paling

15 Peraturan Bupati Lombok Timur Nomor 5 Tahun 2021Tentang Perubahan ke Tiga atas Peraturan Bupati Nomor 15 tahun 2016 tentang Peraturan Pelaksanaan Peraturan Daerah Nomor 4 tahun 2015 Tentang Tata Cara Pemilihan dan Pemberhentian Kepala Desa pasal $14 \mathrm{~A}$

16 Peraturan Bupati Lombok Timur Nomor 5 Tahun 2021 Tentang Perubahan Ke Tiga atas Peraturan Bupati Nomor 15 tahun 2016 Tentang perturan pelaksanaan Peraturan Daerah Nomor 4 tahun 2015 tentang tata cara pemilihan dan pemberhentian kepala Desa pasal 74 ayat (3)

17 Sabrun Maas, wawancara. Pilkades antar waktu di Desa Anjani (25 agustus 2021) lambat dalam jangka waktu 30 (Tiga Puluh Hari) sejak dibentuknya panitia pilkades dalam aturan tersebut juga dijelaskan bahwa persetujuan anggaran pilkades oleh Pejabat Desa disetujui paling lambat dalam jangka waktu 30 ( tiga puluh hari ) sejak diajukan oleh panitia Pilkades.

(4) Pengumuman dan pendaftaran bakal calon Kades pengganti antar waktu.

Dalam pemilihan Kepala Desa antar waktu di Desa Anjani Kecamatan Suralaga Kabupaten Lombok Timur, bakal calon Kepala Desa antar waktu yang mendaftar sebanyak 5 (lima) orang yaitu : (1) Muhammad Said, SP, Umur 55 Tahun, Alamat RT 006 Dusun Anjani Timur; (2) Muhammad Isnaini, Umur 42 Tahun, Alamat Dusun Anjani Selatan Dua; (3) Agus Harianto, Umur 38 Tahun Alamat Dusun Anjani Barat Baru; (4) Muhammad Sapoan, S.Pd.I, Umur 50 Tahun Alamat Dusun Anjani Selatan Satu; dan (5) Azharudin, Umur 47 Tahun, Alamat Dusun Anjani Selatan Satu.

Dalam hal ini sebagaimana tertuang dalam berita acara rapat panitia nomor: 012/Pan PAW-Pilkades/2021 tanggal 22 Maret 2021 tentang hasil penelitian kelengkapan administrasi bakal calon Kepala Desa antar waktu Desa Anjani Kecamatan Suralaga Kabupaten Lombok Timur Tahun 2021.

(5) Penelitian kelengkapan persyaratan administrasi bakal calon Kepala Desa Antar Waktu.

Dalam hal penelitian kelengkapan persyaratan administrasi bakal calon Kepala Desa antar waktu, panitia Pilkades antar waktu Desa Anjani Kecamatan Suralaga mengacu pada Perbup Kabupaten Lombok Timur Nomor 5 Tahun 2021 tentang Perubahan Ke Tiga atas Peraturan Bupati Nomor 15 tahun 2016 tentang Peraturan Pelaksanaan Peraturan Daerah Nomor 4 tahun 2015 tentang tata cara pemilihan dan pemberhentian Kepala Desa pasal 22 yang berbunyi "Calon Kepala Desa wajib memenuhi persyaratan :

a) Warga negara Republik Indonesia;

b) Bertakwa kepada Tuhan Yang Maha Esa;

c) Memegang teguh dan mengamalkan Pancasila, melaksanakan UndangUndang Dasar Negara Republik Indonesia Tahun 1945 serta 
mempertahankan dan memelihara keutuhan Negara Kesatuan Republik Indonesia dan Bhinneka Tunggal Ika;

d) Berpendidikan paling rendah tamat sekolah menengah pertama atau sederajat;

e) Berusia paling rendah 25 (dua puluh lima) tahun pada saat mendaftar;

f) Bersedia dicalonkan menjadi Kepala Desa;

g) Tidak sedang menjalani hukuman pidana penjara;

h) Tidak pernah dijatuhi pidana penjara berdasarkan putusan pengadilan yang telah mempunyai kekuatan hukum tetap karena melakukan tindak pidana yang diancam dengan pidana penjara paling singkat 5 (lima) tahun atau lebih, kecuali 5 (lima) tahun setelah selesai menjalani pidana penjara dan mengumumkan secara jujur dan terbuka kepada publik bahwa yang bersangkutan pernah dipidana serta bukan sebagai pelaku kejahatan berulang-ulang tidak sedang dicabut hak pilihnya sesuai dengan putusan pengadilan yang mempunyai kekuatan hukum tetap;

i) Berbadan sehat;

j) Tidak pernah menjabat sebagai Kepala Desa selama 3 (tiga) kali masa jabatan;

k) Izin tertulis dari pejabat pembina kepegawaian bagi Calon yang berasal dari Pegawai Negeri Sipil;

I) Izin tertulis dari pimpinan/atasan tempat yang bersangkutan bekerja bagi anggota TNI/POLRI, pegawai BUMN/BUMD, dan pegawai swasta;

m) Izin tertulis dari Bupati bagi calon yang berasal dari Kepala Desa dan BPD;

n) Izin tertulis dari Camat bagi calon yang berasal bagi perangkat desa;

o) Mendapatkan dukungan paling sedikit 5 \% (lima perseratus) dari jumlah pemilih yang terdaftar dalam DPS yang dibuktikan dengan fotokopi Kartu Tanda Penduduk yang tersebar dilebih dari $1 / 2$ (satu per dua) jumlah Dusun di Desa tersebut; dan p) Memenuhi kelengkapan persyaratan administrasi pencalonan Kepala Desa. ${ }^{18}$

Beradasarkan hasil cek list kelengkapan administrasi bakal calon Kepala Desa antar waktu Desa Anjani Kecamatan Suralaga Kabupaten Lombok Timur, dari kelima orang bakal calon yang mendaftar dinyatakan lulus administrasi sebagai bakal calon.

Adapun bakal calon Kepala Desa antar waktu yang dinyatakan lulus administrasi adalah: (1) Muhammad Said, SP, Umur 55 Tahun, Alamat RT 006 Dusun Anjani Timur, (2) Muhammad Isnaini, Umur 42 Tahun, Alamat Dusun Anjani Selatan Dua, (3) Agus Harianto, Umur 38 Tahun Alamat Dusun Anjani Barat Baru, (4) Muhammad Sapoan, S.Pd.I, Umur 50 Tahun Alamat Dusun Anjani Selatan Satu, (5) Azharudin, Umur 47 Tahun, Alamat Dusun Anjani Selatan Satu.

Dalam hal ini sebagaimana tertuang dalam berita acara rapat panitia nomor: 012/Pan PAW-Pilkades/2021 tanggal 22 Maret 2021 tentang hasil penelitian kelengkapan administrasi bakal calon Kepala Desa antar waktu Desa Anjani Kecamatan Suralaga Kabupaten Lombok Timur Tahun 2021.

(6) Penetapan calon Kepala Desa antar waktu

Beradasarkan hasil ceklist kelengkapan administrasi oleh panitia pilkades terdapat 5 (Lima) orang bakal calon yang lulus administrasi. Dalam hal jumlah calon lebih dari 3 ( tiga ) orang, panitia melakukan seleksi tambahan. Hal ini diatur dalam Peraturan Menteri Dalam Negeri Nomor 65 tahun 2017 pasal 47 C yang berbunyi :

(1) Panitia pemilihan sebagaimana dimaksud dalam Pasal 47B ayat (3) melakukan penjaringan dan penyaringan bakal calon kepala Desa antar waktu.

(2) Penyaringan bakal calon kepala Desa menjadi calon kepala Desa ditetapkan paling sedikit 2 (dua) orang calon dan paling banyak 3 (tiga) orang calon.

(3) Dalam hal jumlah calon sebagaimana dimaksud pada ayat (2) yang memenuhi persyaratan lebih dari 3 (tiga) orang, panitia melakukan seleksi tambahan.

(4) Seleksi tambahan sebagaimana dimaksud pada ayat (3) terdiri atas:

18 Republik Indonesia.Peraturan Daerah Kabupaten Lombok Timur nomor 4 tahun 2015 tentang tata cara pemilihan dan pemberhentian kepala Desa pasal 22 
a. memiliki pengalaman mengenai pemerintahan Desa;

b. tingkat pendidikan; dan/atau

c. persyaratan lain yang ditetapkan bupati/wali kota. ${ }^{19}$

Dari hasil seleksi tambahan, terdapat 3 ( tiga ) orang bakal calon yang berhak dan ditetapkan menjadi calon Kepala Desa antar waktu Desa Anjani Kecamatan Suralaga kabupaten Lombok Timur yaitu :

(1) Muhammad Said, SP, Umur 55 Tahun, Alamat RT 006 Dusun Anjani Timur,

(2) Muhammad Isnaini, Umur 42 Tahun, Alamat Dusun Anjani Selatan Dua,

(3) Agus Harianto, Umur 38 Tahun, Alamat Dusun Anjani Barat Baru.

Dalam hal ini sebagaimana tertuang dalam Berita Acara Rapat Panitia Nomor: 016/Pan PAW-Pilkades/2021 tanggal 24 Maret 2021 tentang Hasil Penelitian Kelengkapan administrasi bakal calon Kepala Desa antar waktu Desa Anjani Kecamatan Suralaga Kabupaten Lombok Timur Tahun 2021.

(7) Penetapan nomor urut dan tanda gambar calon Kepala Desa

Untuk memudahkan peserta musyawarah/pemilih dalam menentukan pilihan dalam pemungutan suara, nomor urut dan tanda gambar sangat penting diperlukan, berdasarkan lampiran berita acara rapat panitia nomor 020/ Pan PAW Anjani / III / 2021 Tanggal 29 Maret 20121 tentang penetapan nomor urut calon Kepala Desa antar waktu Desa Anjani Kecamatan Suralaga Kabupaten Lombok Timur Tahun 2021, disepakati bahwa :

1) Muhammad Said menempati nomor urut 1 ;

2) Agus Harianto menempati nomor urut 2;

3) Muhammad Isnaeni menempati nomor urut 3.

Adapun untuk tanda gambar, semua calon menggunakan foto/ gambar dari masingmasing calon.

\section{(8) Penetapan Peserta Musyawarah}

Dalam menetapkan jumlah peserta musyawarah khusus Desa, BPD Desa Anjani mengacu pada Permendgri Nomor 65 Tahun

19 Republik Indonesia, Peraturan menteri Dalam Negeri Nomor 65 tahun 2017 tentang pemilihan kepala desa pasal $47 \mathrm{C}$
2017 Tentang Perubahan atas Permendgri Nomor 112 tahun 2014 Tentang Pemilihan Kepala Desa pasal 47 D ayat (7) yang berbunyi :

"Jumlah peserta musyawarah Desa sebagaimana dimaksud pada ayat (4) dan ayat (5) dibahas dan disepakati bersama BPD dan pemerintah Desa dengan memperhatikan jumlah penduduk yang mempunyai hak pilih di Desa yang ditetapkan dengan keputusan BPD ". 20

Sedangkan ketentuan Perbup No. 15 Tahun 2016 tentang Tata Cara Pemilihan dan Pemberhentian Kepala Desa, pasal 72 menyatakan, "penyelenggaraan musyawarah desa dilakukan oleh BPD, pelaksanaan penetapan calon dan pemilihan melalui musyawarah mufakat atau melalui pemungutan suara".

Berdasarkan muatan pasal tersebut, BPD Desa Anjani menyepakati 2,5 \% (dua koma lima persen) dari jumlah DPT (Daftar Pemilih Tetap) Desa Anjani yang akan menjadi peserta musyawarah khusus Desa. Mengingat jumlah DPT Desa Anjani tahun 2021 berjumlah 7.000 (tujuh ribu) orang, sehingga ditetapkan sebanyak 175 orang peserta musyawarah, terdiri dari 158 orang laki-laki dan 17 orang perempuan. Dalam hal ini mewakili unsur-unsur dari masyarakat sebagai berikut : Unsur Tokoh Agama

38 Orang, Tokoh Masyarakat $89 \quad$ Orang, Tokoh Pendidikan 5 Orang, Perwakilan Kelompok Tani8 Orang, Perwakilan Kelompok Perempuan 18 Orang, Tokoh Pemuda 17 Orang, Calon Kepala Desa 3 Orang.

Menurut Keterangan Nurmin selaku ketua BPD Anjani disepakati juga bahwa anggota BPD, Pj Kades, Sekdes, Kaur, Kasi, Kawil, LKMD, dan BKD tidak ikut menjadi peserta musyawarah dengan alasan untuk menjaga kenetralan dan kondusifitas selama proses pelaksanaan dan setelah pemilihan serta diharapkan berjalannya roda pemerintahan Desa dengan baik, nyaman dan tidak ada saling tuduh menuduh tentang dukungan calon Kepala Desa tertentu antar

20 Undang-Undang Republik Indonesia.Peraturan Menteri Dalam Negeri Nomor 65 Tahun 2017 Tentang Perubahan atas Peratuaran Menteri Dalam Negeri Nomor 112 tahun 2014 Tentang Pemilihan Kepala Desa pasal $47 \mathrm{D}$ ayat (7) 
jajaran pemerintah Desa setelah ditetapkannya calon Kepala Desa terpilih. ${ }^{21}$

Hal ini tertuang dalam Berita Acara Rapat tanggal 25 Maret 2021 tentang penentuan jumlah peserta musyawarah dalam pemilihan Kepala Desa antar waktu Desa Anjani Kecamatan Suralaga Kabupaten Lombok Timur Tahun 2021, yang selanjutnya dituangkan dalam Keputusan BPD Anjani. Dalam menentukan peserta musyawarah desa yang berasal dari unsur masyarakat sebagaimana yang tercantum dalam Permendagri Nomor 65 tahun 2017 pasal 47D ayat (5), BPD Anjani mengabaikan beberapa unsur atau perwakilan dari masyarakat diantaranya yaitu, unsur tokoh adat, perwakilan nelayan, perwakilan kelompok perajin, perwakilan kelompok pemerhati dan perlindungan anak dan perwakilan masyarakat miskin.

Tokoh adat tidak memiliki perwakilan menjadi peserta pemilihan dengan alasan Desa Anjani bukan termasuk Desa adat dan tidak adanya lembaga adat di Desa anjani. Adapun untuk perwakilan nelayan dan perajin tidak diakomodir karena tidak adanya masyarakat yang berprofesi sebagai nelayan dan perajin, begitu juga dengan perwakilan kelompok pemerhati dan perlindungan anak tidak diikutkan karena tidak ada lembaga resmi terkait kelompok pemerhati dan perlindungan anak.

Sedangkan untuk perwakilan masyarakat miskin, secara tektual tidak disebutkan perwakilan masyarakat miskin tetapi sudah terakomodir di dalam unsur masyarakat lainnya dengan alasan menyebut masyarakat sebagai orang miskin itu dianggap kurang beretika dan tidak adanya juknis secara tertulis bagaimana menentukan ketika masyarakat miskin itu lebih dari satu, dua,tiga dan seterusnya, sehingga dikhawatirkan menjadi polemik bagi para calon Kepala Desa ketika ada masyarakat kategori miskin yang merupakan keluarga salah satu calon, tetapi tidak terakomodir karena banyaknya masyarakat yang termasuk kategori miskin. ${ }^{22}$ Hal ini tentunya mengurangi tingkat keterwakilan unsur dari

\footnotetext{
21 Nurmin.wawancara.Pemilihan kepala Desa antar waktu di Desa Anjani (28 September 2021)

22 Nurmin.wawancara.pilkades antar waktu di Desa anjani (8 September 2021)
}

masyarakat dalam menentukan siapa pemimpin Desa yang akan melanjutkan sisa jabatan Kepala Desa sebelumnya.

(9) Musyawarah Khusus Desa pemilihan

Kepala Desa antar waktu

Mekanisme pemilihan Kepala Desa antar waktu sebagaimana dijelskan dalam UU Desa pasal 45 b ayat (3) disebutkan bahwa:

'pelaksanaan pemilihan calon Kepala Desa oleh panitia pemilihan melalui mekanisme musyawarah mufakat atau melalui pemungutan suara yang telah disepakati oleh musyawarah Desa."

Untuk mekanisme pemilihan Kepala Desa antar waktu di Desa Anjani Kecamatan Suralaga Kabupaten Lombok Timur menggunakan mekanisme pemilihan. Hal ini tertuang dalam Berita Acara Musyawarah Desa Nomor 020/Pan-PAW Anjani/III/2021 tanggal 31 maret 2021 tentang Pemilihan Kepala Desa Antar Waktu Desa Anjani Kecamatan Suralaga Kabupaten Lombok Timur Tahun 2021.

Adapun prosedur Musyawarah Desa tersebut adalah sebagai berikut:

1) Persiapan

2) Pelaksanaan pemungutan suara

Pemungutan suara dilaksanakan pada hari Rabu tanggal 31 Maret 2021, dimulai pukul 07.00 Wita dan ditutup pada pukul 11.00 Wita. Dari total pemilih yang berjumlah 175 orang, semua pemilih menggunakan hak pilinnya dalam pemilihan tersebut.

3) Perhitungan Suara

Proses perhitungan suara dimulai pada pukul 11.00 Wita dan berakhir pada pukul 12.00 Wita. Adapun hasil perhitungan suara masing-masing calon adalah sebagai berikut:

a) Calon Nomor Urut 1, atas nama Muhammad Said memperoleh 81 (delapan puluh satu) suara ;

b) Calon Nomor Urut 2, atas nama Agus Harianto memperoleh 23 (dua puluh tiga) suara;

c) Calon Nomor urut 3, atas nama Muhammad Isnaeni memperoleh 71 (tujuh puluh satu) suara.

Jumlah suara sah sebanyak 175 (seratus tujuh puluh lima) dan jumlah suara tidak sah sebanyak 0 (nol). Sebagaimana 
tertuang dalam Sertifikat Hasil Perhitungan Suara pemilihan Kepala Desa Anjani Kecamatan Suralaga Kabupaten Lombok Timur Tahun 2021.

(10)Rapat Penetapan Calon kepala Desa Terpilih

Berdasarkan hasil perhitungan suara yang dilaksanakan pada tanggal 24 Maret 2021, ditetapakan calon nomor urut 1 atas nama Muhammad Said Umur 55 Tahun, Alamat RT 006 Dusun Anjani Timur, dengan total perolehan suara sebanyak 81 ( Delapan puluh satu ) suara sebagai calon Kepala Desa terpilih dalam pemilihan Kepala Desa antar waktu di Desa anjani Kecamatan Suralaga Kabupaten Lombok Timur Tahun 2021, sebagaimana yang tertuang dalam Keputusan Panitia Pemilihan Nomor 02/Pan-PAW Anjani/III/2021 tanggal 31 Maret 2021 tentang Penetapan calon Kepala Desa antar waktu Desa Anjani Kecamatan Suralaga Kabupaten Lombok Timur periode 20212024.

\section{(11)Pelaporan Hasil Pilkades Antar Waktu}

Pelaporan hasil Pilkades oleh panitia pemilihan dilaksanakan melalui musyawarah Desa. Hal ini diatur dalam Permendagri Nomor 65 Tahun 2017 pasal 47 D ayat (8) bahwa "Tahapan pelaporan sebagaimana dimaksud pada ayat (1) huruf c meliputi:

a) Pelaporan hasil pemilihan kepala Desa melalui musyawarah Desa kepada BPD dalam jangka waktu 7 (tujuh) hari setelah musyawarah Desa mengesahkan calon kepala Desa terpilih;

b) Pelaporan calon kepala Desa terpilih hasil musyawarah Desa oleh ketua BPD kepada Bupati/Wali kota paling lambat 7 (tujuh) hari setelah menerima laporan dari panitia pemilihan;'23

Sedangkan ketentuan pasal 72 huruf $d$, e, $f$ dan $g$ Peraturan Bupati Nomor 15 tahun 2016 tentang Peraturan Pelaksanaan Peraturan Daerah Nomor 4 tahun 2015 tentang tata cara pemilihan dan pemberhentian Kepala Desa, menguraikan yaitu "pelaporan hasil pemilihan calon kades disampaikan oleh panitia pemilihan kepada musyawarah desa, pengesahan calon kepala

${ }^{23}$ Republik Indonesia Permendagri nomor 65 tahun 2017 pasal 47 D ayat (8) desa oleh musyawarah desa dan dalam jangka waktu 7 hari wajib menyampaikan laporan kepada BPD, selanjutnya BPD dalam jangka 7 hari wajib menyampaikan laporan kepada bupati".

Pelaporan disusun oleh panitia pemilihan sebanyak 3 (Tiga) rangkap, satu rangkap diserahkan ke Kabupaten sebagai syarat untuk diterbitkannya Surat Keputusan pengankatan Kepala Desa terpilih antar waktu. Sebagaimana tertuang dalam berkas Iaporan calon Kepala Desa terpilih Kepala Desa antar waktu nomor 022/Pan-PAW Anjani/III/2021 tanggal 31 Maret 2021.

(12)Pelantikan Kepala Desa Antar Waktu

Proses pelantikan Kepala Desa antar waktu terpilih Desa Anjani dilaksanakan pada tanggal 14 April 2021, di Aula Yayasan Sullamul Mubtadi Desa Anjani. yang dihadiri oleh diantaranya Camat Suralaga, Panitia Pilkades, BPD Anjani dan unsur masyarakat Desa Anjani. Kepala Desa Anjani terpilih Muhammad Said, SP dilantik oleh Camat Suralaga atas nama Bupati Lombok Timur. ${ }^{24}$

Pelantikan Kepala Desa dilaksanakan setelah terbitnya Surat Keputusan Bupati Lombok Timur Nomor: 188.45/251/PMD/2021 tentang Pengangkatan dan Penetapan Muhammad Said, SP sebagai Kepala Desa terpilih antar waktu Desa Anjani Kecamatan Suralaga Kabupaten Lombok Timur dengan periode masa jabatan 2021-2024.

\section{Faktor Pendukung dan Penghambat Pemilihan Kepala Desa Anjani}

(1) Faktor Pendukung

a) Faktor Internal

Adanya kebutuhan yang sangat diperlukan untuk mengisi kekosongan jabatan Kepala Desa di Desa Anjani yang diakibatkan oleh meninggalnya Kepala Desa sebelumnya.

Pemilihan Kepala Desa antar waktu di Kabupaten Lombok Timur khususnya di Desa Anjani merupakan suatu model pemilihan yang baru setelah lahirnya UU Desa, sesuatu hal yang baru tentunya butuh sumber daya manusia yang

24 Abdul hakim.wawancara.Pilkades antar waktu di Desa Anjani (26 Agsutus 2021) 
handal dalam mengawal atau mensukseskan pelaksanaanya.

Panitia pemilihan Kepala Desa antar waktu Desa anjani merupakan orang-orang yang sudah berpengalaman dalam melaksanakan pemilihan, baik itu Pilkades, Pilkada, Pileg bahkan Pilpres. Terbukti dari semua tahapan dan proses pilkades antar waktu sudah sesuai dengan peraturan yang berlaku walaupun masih perlu penyempurnaan.

b) Faktor Ekternal

Suksesnya Pilkades antar waktu di Desa Anjani tidak terlepas juga adanya kerjasama yang baik, dukungan dan kritikan yang sifatnya membangun antara Dinas Pemberdayaan Masyarakat Desa (PMD) Kabupaten Lombok Timur, Camat Suralaga, BPD, Pemerintah Desa, panitia pemilihan dan masyarakat, sehingga setiap diadakan rapat selama proses Pilkades antar waktu ini selalu mendapatkan kesepakatan yang memuaskan semua pihak demi suksesya pelaksanaan pilkades tersebut. Hal inilah yang menjadi faktor pendukung suksesnya pelaksanan Pilkades antar waktu di Desa anjani Kecamatan suralaga Kabupaten Lombok Timur.

(2) Faktor Penghambat

Sebagaimana yang telah penulis jelaskan sebelumnya bahwa Pilkades antar waktu ini adalah model baru dalam pemilihan Kepala Desa, tentunya masih banyak faktor yang sedikit menghambat dalam pelaksanaanya.

Ada beberapa hal yang menghambat dalam proses pemilihan kepala Desa antar waktu di Desa Anjani yaitu :

a) Peraturan yang tidak komprehensif yang mengatur khusus tentang Pilkades antar waktu ditingkat Perda maupun Perbup Kabupaten Lombok Timur, sehingga dalam proses pelaksanaannya panitia harus datang langsung ke Kabupaten atau Dinas terkait untuk meminta penjelasan terkait permasalahan yang dihadapi terutama dalam hal mekanisme menentukan peserta musyawarah Desa.
Menurut keterangan dari Suherman, selaku Kasubag Perundang-Undangan bagian hukum Sekda Kabupaten Lombok Timur, dia menjelaskan bahwa keberadaan perda atau Perbub yang khusus tentang Pilkades PAW memang tidak ada, tetapi sudah menyatu dengan perda atau perbup yang mengatur tentang tata cara pemilihan dan pemberhentian Kepala Desa karena pada dasarnya proses pilkades serentak maupun pilkades PAW adalah sama yang membedakan hanya mekanismenya saja.

Selanjutnya mengenai kriteria unsurunsur masyarakat yang menjadi peserta musyawarah khusus Desa atau Pemilih dalam pilkades PAW, dia menjelaskan bahwa keriteria dari unsur masyarakat itu tidak terlepas dari kearifan lokal masing-masing desa, sehingga tidak dirumuskan dalam suatu Perda atau Perbup, melainkan berdasarkan hasil kesepakatan musyawarah desa setempat. ${ }^{25}$

Selanjutnya menurut keterangan Zarwin, selaku Kasi pemerintahan Kecamatan Suralaga, dari segi Perda maupun Perbub Kabupaten Lombok Timur yang khusus mengenai Pilkades PAW memang tidak ada, karena Pilkades PAW dengan pilkades pada umumnya hanya sedikit perbedaan sehingga proses pendaftran calon, proses seleksi pencalonan dan penetapan calon mengacu pada Perda maupun Perbup yang mengatur tentang tata cara pemilihan dan pemberhentian Kepala Desa. ${ }^{26}$

Selanjutnya menurut keterangan Muhammad Said selaku calon Kepala Desa PAW terpilih, menjelaskan bahwa peraturan yang menjadi acuan dalam pilkades PAW Desa Anjani Kecamatan Suralaga adalah perda dan perbub yang berkaitan dengan tata cara pemilihan dan pemberhentian Kepala Desa, Permendagri Nomor 65 tahun 2017 namun dia menambahkan bahwa tidak ada perda ataupun perbup Lombok

25 Suherman. Wawancara pilkades antar waktu (1 oktober 2021)

26 Zarwin.wawancara pilkades antar waktu (30 september 2021) 
Timur yang khusus mengenai Pilkades PAW sehingga proses pendaftaran, proses seleksi dan penetapan calon masih mengacu pada Perda atau Perbup yang mengatur tentang tata cara pemilihan dan pemberhentian Kepala Desa. ${ }^{27}$

b) Biaya pemilihan yang dibebankan dari APBDes juga cukup menghambat proses pelaksanaannya, karena pemerintah Desa harus merubah alokasi anggaran dan peruntukannya yang sudah di sepakati dalam musyawarah desa yang membutuhkan waktu dalam proses perubahannya. Hal inilah yang menjadi faktor penghambat pelaksanaan Pilkades antar waktu di Desa Anjani Kecamatan suralaga Kabupaten Lombok Timur tahun 2021.

\section{PENUTUP}

Pemilihan Kepala Desa antar waktu di Desa Anjani Kecamatan Suralaga Kabupaten Lombok Timur Tahun 2021 diselenggarakan berlandaskan pada Undang-Undang Dasar Negara Republik Indonesia Tahun 1945, Undang-Undang Nomor 6 Tahun 2014 tentang Desa, Peraturan Pemerintah Nomor 43 Tahun 2014 tentang Peraturan Pelaksana UU Nomor 6 Tahun 2014 tantang Desa, Peraturan Menteri Dalam Negeri Nomor 65 Tahun 2017 tentang perubahan atas Peraturan Menteri Dalam Negeri Nomor 112 Tahun 2014 tentang Pemilihan Kepala Desa, Peraturan Daerah Kabupaten Lombok Timur Nomor 4 Tahun 2015 tentang tata cara pemilihan dan pemberhentian Kepala Desa, Peraturan Bupati Lombok Timur nomor 5 tahun 2021 tentang perubahan ke tiga atas Peraturan Bupati Lombok Timur nomor 15 tahun 2016 tentang Tata Cara Pemilihan dan Pemberhentian Kepala Desa dan Surat Keputusan Bupati Lombok Timur Nomor 188.45/571/PMD/2020 Tanggal 26 Oktober 2020 Tentang Pengangkatan Pejabat Kepala Desa Anjani Kecamatan Suralaga Kabupaten Lombok Timur yang tugas utamanya adalah melaksanakan pemilihan Kepala Desa antar waktu.

Pelaksanaan Pemilihan Kepala Desa antar waktu di Desa Anjani Kecamatan

\footnotetext{
27 Muhammad Said.wawancara pilkades antar waktu
} (29 september 2021)
Suralaga Kabupaten Lombok Timur Tahun 2021 dilaksanakan melalui mekanisme pemilihan. Dalam hal penentuan peserta musya warah Desa, Panitia pemilihan dan BPD Anjani mengabaikan beberapa unsur atau perwakilan dari masyarakat diantaranya yaitu , Unsur tokoh adat, perwakilan nelayan, perwakilan kelompok perajin, perwakilan kelompok pemerhati dan perlindungan anak serta perwakilan masyarakat miskin.

Hal ini dikarenakan tidak adanya pedoman tekhnis terkait keriteria dari unsur masyarakat sebagaimana yang tertuang dalam Permendagri Nomor 65 tahun 2017 tentang perubahan atas Permendagri Nomor 112 Tahun 2014 tentang pemilihan Kepala Desa. Walaupun demikian, tidak terlibatnya beberapa unsur masyarakat tersebut diatas, sudah disepakati bersama dan sudah dikonsultasikan kepada pihak terkait, sehingga tidak ada masalah yang timbul selama proses pemilihan sampai dilantiknya calon Kepala Desa terpilih antar waktu.

Tingkat partisipasi pemilih dalam hal memberikan hak suara sangat tinggi, hal ini dapat dilihat dari jumlah pemilih hasil musyawarah yang berjumlah 175 orang, semuanya menggunakan hak pilihnya. Suksesnya pemilihan Kepala Desa antar waktu di Desa Anjani Kecamatan Suralaga Kabupaten Lombok Timur Tahun 2021 didukung oleh Sumber Daya Manusia yang sudah berpengalaman dalam melaksanakan suatu pemilihan, baik tingkat Desa maupun tingkat Nasional, serta adanya kerja sama yang baik antara panitia pemilihan, Pemerintah Desa, BPD dan pihak terkait lainnya. Keterbatasan Pedoman Tekhnis terutama Peraturan Daerah dan Peraturan Bupati Lombok Timur yang khusus terkait pemilihan Pilkades antar waktu menjadi kendala atau penghambat utama pelaksanaan pemilihan Kepala Desa antar waktu di Desa Anjani Kecamatan Suralaga Kabupaten Lombok Timur tahun 2021.

Dalam hal tahapan pemilihan Kepala Desa antar waktu, seharusnya dalam Peraturan yang mengatur tentang pemilihan Kepala Desa antar waktu, ada tahapan tentang kampanye atau penyampaian Visi dan Misi para calon Kepala Desa antar waktu, karena hal ini sangat penting bagi peserta musyawarah atau pemilih untuk mendapatkan gambaran siapa yang layak 
dan patut dijadikan pemimpin Desa, walaupun calon Kepala Desa yang terpilih nantinya hanya untuk melanjutkan atau mengisi sisa jabatan Kepala Desa sebelumnya. Untuk Kelancaran Pelaksanaan Pilkades antar waktu berikutnya, Pemerintah Daerah Kabupaten Lombok Timur supaya segera membuat Perda atau Perbup yang lebih tekhnis terkait Pilkades antar waktu terutama dalam hal menentukan keriteria unsur masyarakat yang menjadi peserta musyawarah, supaya panitia dan BPD tidak menafsirkan sendiri unsur masyarakat yang sudah tertera dalam peraturan yang ada, sehingga hasil penafsiran itu tidak dimanfaatkan oleh oknum tertentu yang bisa menimbulkan permasalahan dikemudian hari.

\section{DAFTAR PUSTAKA}

\section{Buku, Makalah dan Artikel}

Basri Mulyani dan Zainul Fikri, 2015. Perilaku Memilih: Analisis Terhadap Tingginya Surat Suara Tidak Sah (Studi Kasus Kota Mataram)

http://repository.ugr.ac.id:1015/18/ (diakses 08 Juni 2021). et al, 2020, Pedoman Penulisan Karya ilmiah, Fakultas Hukum Universitas Gunung Rinjani, https://law.ugr.ac.id/download/pedoma n-penulisan-karya-ilmiah/

Departemen Pendidkan Nasional. 2003. Kamus Besar BahasaIndonesia.Edisi ke 3, Jakarta: Balai Pustaka.

H.A.W Widjaja. 2003.Otonomi Desa Merupakan Otonomi Yang asli, Bulat dan Utuh.Jakarta : Raja Grafindo Persada.

Muhammad, Abdul Kadir. 2004. Hukum dan Penelitian Hukum. Cet. Pertama. Bandung: PT Citra Aditya Bakti.

Moleong, L.J. Metodologi Penelitian. Bandung: PT Remaja Rosda Karya, 1999

Soekanto, Soerjono, Pengantar Penelitian Hukum, UI Press; Jakarta, 1986

Sugiman. Pemerintah Desa. http://medianeliti.com (di akses pada tanggal 21 Mei 2021)

Sugiyuno, 2017. Metode Penelitian Kualitatif. Bandung: PT Alfabeta
Zainuddin Ali, 2009. Metode Penelitian Hukum. Jakarta: Sinar Grafika

\section{Peraturan Perundang-undangan:}

Undang-Undang Dasar Negara Republik Indonesia Tahun 1945

Undang Undang Nomor 6 Tahun 2014 tentang Desa

Peraturan Pemerintah Nomor 43 Tahun 2014 tentang Peraturan Pelaksanaan Undang-Undang Nomor 6 Tahun 2014 tentang Desa

Peraturan Menteri Dalam Negeri Nomor 65 Tahun 2017 tentang perubahan atas peraturan Menteri Dalam Negeri Nomor 112 tahun 2014 tentang Pemilihan Kepala Desa.

Peraturan Menteri dalam Negeri Nomor 110 tahun 2016 tentang Badan Permusyawaratan Desa

Peraturan Daerah Kabupaten Lombok Timur Nomor 4 Tahun 2015 tentang Pemilihan Kepala Desa.

Peraturan Bupati Lombok Timur Nomor 5 tahun 2021 atas Perubahan Ke Tiga Peraturan Bupati Lombok Timur Nomor 15 Tahun 2016 tentang tata cara pemilihan dan pemberhentian Kepala Desa 